\title{
LIVED EXPERIENCES OF MOTHER TONGUE-BASED TEACHERS IN IP SCHOOLS: STORIES TO TELL
}

\author{
Jonathan P. Corlet, Mary Ann E. tarusan \\ University of Mindanao, Davao City
}

Article DOI: https://doi.org/10.36713/epra9627

DOI No: 10.36713/epra9627

\begin{abstract}
This study's general objective was successfully achieved by revealing the lived experiences of Mother Tongue-Based teachers in IP schools that implement the MTB-MLE. This qualitative research utilized the phenomenological design and secured the rich data from the in-depth interview and focus group discussion of the lived experiences of Mother Tongue-Based teachers in IP schools. There were eight teacher-participants for the in-depth interviews and seven teacher-participants for the focus group discussion from public elementary schools in the IP communities. The IP school teachers' experiences, both positive and negative, or even if it shows ease or difficulties, were recorded, interpreted, and analyzed through thematic analysis extracted all the essential themes from the participants' responses. It has been observed that all the participants provided a positive and negative feedback on the Mother Tongue implementation. The struggles of Mother Tongue-Based teachers in IP schools developed essential themes such as Highly tasking instructional responsibilities, Challenging use of native dialects, Difficulty with unfamiliar terminologies, Negative effects on English literacy, and Aiming for positive learning outcomes. On the coping strategies employed by the MTBMLE teachers, the following themes were observed: Self-retooling activities, Diversified teaching methods, Contextualized instructional delivery, Individualized instructions, and Acquaintance with the community. While on the insights shared by MTB-MLE teachers to the community, developed these themes: Need for social support, Provision of in-service training, Deep understanding of learner's needs, Enhancement of student-teacher relationship, and Enrichment of native languages.
\end{abstract}

KEYWORDS: multilingual education, mother tongue, lived experiences, phenomenology, challenges, coping strategies, IP school teachers, Philippines

\section{RATIONALE}

As an elementary teacher, I witnessed how my fellow educators dealt with the difficulties in handling mother tongue in their classroom instructions despite the many benefits charted for MTB-MLE. First, instructional materials, resources, and supplies were not readily obtainable in most local dialects like some of the IP schools with cultural dialects such as the Bagobo and the Matigsalug. Second, teachers assigned in some of the IP schools, particularly in the elementary level, were not trained in the local dialects with the fact that they are not experts of the native languages (e.g., Bagobo and Matigsalug) used for instruction where they were stationed to teach. Third, elementary school teachers might not have any solid preparation for Mother Tongue or English learning study and theories. Furthermore, teachers assigned in IP schools do not belong to the tribal community that makes it hard for them to relay and instruct IP learners.
In this case, this study may help our indigenous brothers and sisters to preserve their native language aside from the fact that these languages are now threatened to be extinct. This study will be of great help for the teachers teaching in IP to share their experiences in handling IP learners and teaching Sinugbuanong Bisaya as a subject and medium of instruction to the IP learners whose dialects are Bagobo and Matigsalug.

In this study, theory was utilized to explain the productive way of coping with the struggles experienced by the teachers who are teaching MTB-MLE in IP schools. Theories provide new notions of the implementation and application of new skills and innovations in language teaching as identified in this study. Particularly, the Humanist Theory emphasized the experiences of the teachers' experiences and the conclusions of such experiences. 


\section{PURPOSE OF THE STUDY}

This study's nature and the general objective of this study was to extract the lived experiences of Mother TongueBased teachers in IP schools implementing the MTB-MLE. This study's purpose was to provide reflective ideas from the insights and lessons learned based on their struggles and difficulties encountered in teaching MTB-MLE in IP Schools. The teachers' lived experiences showed how these mandates utilized the MTB-MLE in aiding our teachers who handled MTB in IP school and learners whose first language is not the Sinugbuanong Bisaya. This study utilized the phenomenological study that pursued the documentation and analysis of the teachers' experiences in the primary levels whose learners are members of the indigenous community with a unique cultural language.

The IP school teachers' lived experiences, both positive and negative, were recorded, and interpreted through a series of in-depth interviews, focus group discussions, and thematic analysis. It has more significant contribution to literature, mainly because only a few researchers and scholars have the guts to investigate and discuss through factual analysis the washback of MTB-MLE in language education.

The generated implications for educational practice shared by the MTB-MLE teachers in IP schools served as the contribution of this study. Hence, this further showed the answers on how to preserve the endangered dialects or languages that were endemic in our localities, such as the Bagobo and Matigsalug. The insights shared by the MTBMLE teachers in IP schools also provided inspiration for the novice teachers who wish to teach in IP schools someday.

\section{RESEARCH QUESTIONS}

The researcher's task was to describe and investigate a phenomenon involving teachers' experiences who handled IP learners and taught MTB-MLE. This study has the following research questions:

1. What are the struggles and difficulties of Mother Tongue - Based teachers in IP schools?

2. What are the coping strategies that the Mother Tongue - Based teachers employ?

3. What are the insights and lessons learned by Mother Tongue - Based teachers that they can share in the community?

\section{Theoretical Lens}

The researcher was guided by the theoretical perspectives through the lens of Constructivism founded by John Dewey (1998), the Normalization Process Theory developed and introduced by Carl R. May and Tracy Finch (2012) and the Humanist Theory by Rogers (1960). In the perception of constructivism theory, learners were encouraged to realize the central idea through discovery learning and understanding. Learning about vocabulary by playing strips of words; used of manipulative in learning about additions and subtractions; or learning the impacts, effects, and relationships of subjects with objects through experiments with different sizes and shapes of objects were examples which motivated students in learning (Suhendi \& Purwarno 12).

\section{Significance of the Study}

This ingenuity to fully implement the MTB-MLE was brought based on the lessons, findings, and conclusions of primary local findings and international studies in the elementary education sector which have validated, corroborated, and claimed the superiority of the use of learner's mother tongue or first language (Jorolan-Quintero 762). Consequently, this study's global significance in this modern era was to discuss the predominant public schools' model around the globe that education has been that notion of "one size fits all." This study facilitated the readers to open their eyes to the reality that in implementing MTB-MLE, various considerations must be thoroughly discussed by countries who had more than two languages before implementing or adopting it. This research's social value was visible in this study's results, wherein teachers' lived experiences described the properties of teaching the borrowed MT from the larger society.

The Department of Education in Davao City will directly benefit from this study. The researcher's main goal was to interpret the teachers' lived experience in teaching MTB in an IP school, and this led to a discovery of means and innovations on how to use the native language of Bagobo and Matigsalug tribe and preserved their cultural identity. The teachers assigned in the IP schools gained benefits as they were directed in a series of comprehensive training by the key person who knows the native languages. Besides that, the output of instructional materials and innovations shared by the teachers in IP schools provided realization to have more of these which were applicable also in some other schools. Other regions across the country may also benefit from this study by conducting future studies containing subjects (local or native language present) in their specific or own localities.

\section{RESULTS}

This chapter described the results of the study based on the information analysis of the qualitative data. The presentation of the results of the qualitative data included the thematic analysis of the lived experiences of the Mother Tongue-Based teachers in IP schools. The findings with their lived experiences showed the participants' challenges, coping mechanisms, and insights in teaching the Mother Tongue-Based instruction to the IP learners. It also described the analysis of the transcriptions from the conducted In-Depth Interviews (IDI) and Focus Group Discussions (FGD). 


\section{Profile of the Participants}

Eight research participants took part in the in-depth interview (IDI) while were seven joined the focus group discussion (FGD), as shown in Table 1. Further, the table below shows the profile of the research participants, wherein most of them are from urban areas. Additionally, eight participants were

Table 1.

\begin{tabular}{|c|c|c|c|c|c|}
\hline $\begin{array}{l}\text { Codes of the } \\
\text { Participants }\end{array}$ & $\begin{array}{l}\text { Years in } \\
\text { Service }\end{array}$ & Age & Sex & $\begin{array}{l}\text { Study Group } \\
\text { Classifications }\end{array}$ & Grade Level \\
\hline IDI.TR1 & 3 & 26 & Female & IDI & Grade 1 \\
\hline IDI.TR2 & 3 & 37 & Female & IDI & Grade 2 \\
\hline IDI.TR3 & 2 & 27 & Female & IDI & Grade 3 \\
\hline IDI.TR4 & 7 & 27 & Female & IDI & Grade 2 \\
\hline IDI.TR5 & 5 & 38 & Female & IDI & Grade 2 \\
\hline IDI.TR6 & 6 & 45 & Female & IDI & Grade 1 \\
\hline IDI.TR7 & 5 & 29 & Male & IDI & Grades $2 \& 3$ \\
\hline IDI.TR8 & 3 & 28 & Female & IDI & Grade 2 \\
\hline FGD.TR1 & 3 & 26 & Female & FGD & Grades $1 \& 2$ \\
\hline FGD.TR2 & 3 & 28 & Female & FGD & Grades $3 \& 4$ \\
\hline FGD.TR3 & 7 & 30 & Female & FGD & Grades $1 \& 2$ \\
\hline FGD.TR4 & 4 & 41 & Female & FGD & Grade 1 \\
\hline FGD.TR5 & 4 & 27 & Female & FGD & Grades $3 \& 4$ \\
\hline FGD.TR6 & 7 & 37 & Female & FGD & Grades $2 \& 3$ \\
\hline FGD.TR7 & 3 & 30 & Female & FGD & Grades $1 \& 2$ \\
\hline
\end{tabular}

$\begin{array}{cccccc}\begin{array}{c}\text { Codes of the } \\ \text { Participants }\end{array} & \begin{array}{c}\text { Years in } \\ \text { Service }\end{array} & \begin{array}{c}\text { Profile of the Research Participants } \\ \text { Age }\end{array} & \text { Sex } & \begin{array}{c}\text { Study Group } \\ \text { Classifications }\end{array} & \text { Grade Level } \\ \text { IDI.TR1 } & 3 & 26 & \text { Female } & \text { IDI } & \text { Grade } 1 \\ \text { IDI.TR2 } & 3 & 37 & \text { Female } & \text { IDI } & \text { Grade } 2 \\ \text { IDI.TR3 } & 2 & 27 & \text { Female } & \text { IDI } & \text { Grade } 3 \\ \text { IDI.TR4 } & 7 & 27 & \text { Female } & \text { IDI } & \text { Grade } 2 \\ \text { IDI.TR5 } & 5 & 38 & \text { Female } & \text { IDI } & \text { Grade } 2 \\ \text { IDI.TR6 } & 6 & 45 & \text { Female } & \text { IDI } & \text { Grade } 1 \\ \text { IDI.TR7 } & 5 & 29 & \text { Male } & \text { IDI } & \text { Grades } 2 \& 3 \\ \text { IDI.TR8 } & 3 & 28 & \text { Female } & \text { IDI } & \text { Grade } 2 \\ \text { FGD.TR1 } & 3 & 26 & \text { Female } & \text { FGD } & \text { Grades } 1 \& 2 \\ \text { FGD.TR2 } & 3 & 28 & \text { Female } & \text { FGD } & \text { Grades } 3 \& 4 \\ \text { FGD.TR3 } & 7 & 30 & \text { Female } & \text { FGD } & \text { Grades } 1 \& 2 \\ \text { FGD.TR4 } & 4 & 41 & \text { Female } & \text { FGD } & \text { Grade } 1 \\ \text { FGD.TR5 } & 4 & 27 & \text { Female } & \text { FGD } & \text { Grades } 3 \& 4 \\ \text { FGD.TR6 } & 7 & 37 & \text { Female } & \text { FGD } & \text { Grades } 2 \& 3 \\ \text { FGD.TR7 } & 3 & 30 & \text { Female } & \text { FGD } & \text { Grades } 1 \& 2\end{array}$

teaching monograde or handling one grade level, while seven were teaching in multigrade levels. The participants' years in service showed from two to seven years in teaching IP learners in IP schools. Their age ranges from 26 to 45 years old, and most of them are females.

Profile of the Research Participants

These teachers were chosen based on the criteria on the inclusion and exclusion set in this study which included the actuality that these teachers should be teaching or implementing the use of mother tongue-based instructions in IP schools. Those teachers who were not teaching IP learners and not teaching mother tongue were not included in the study. As seen in the table below, teachers were assigned mostly in Grades 1-3, which indicated that they were using mother tongue-based instruction in their teaching as stipulated in the K-12 Basic Education Curriculum.

\section{The Struggles and Difficulties of Mother Tongue-Based Teachers in IP Schools}

Based on the transcribed lived experiences of the teacher-participants during the IDI and FGD, the researcher coded the participants' responses and had identified the themes with the corresponding core ideas generated under each research question. While discussing the first research questions with the participants of both IDI and FGD, the researcher observed that the participants were very active in sharing their experiences and thoughts in the struggles and difficulties they had encountered.

As presented in table number 2, the struggles of Mother tongue-based teachers in IP schools contained the following essential themes: Highly tasking instructional responsibilities, Challenging use of native dialects, Difficulty with unfamiliar terminologies, Negative effects on English proficiency, and Aiming for positive learning outcomes. The core ideas in each theme were also presented based on the transcribed responses from the research participants.

\section{Coping Strategies Employed by Mother Tongue-Based Teachers in IP Schools}

The next research objective was learning what the coping strategies were employed by our Mother Tongue-Based teachers who were assigned in different IP schools. The role of the Mother Tongue-Based teachers assigned in different IP schools was to additionally provides strategies and techniques in language teaching.

During the actual gathering of data, the researcher observed that the respondents, when asked about their coping strategies on the problems they had encountered, were delighted to share their thoughts and experiences. They were happy because they finally realized their sacrifices and what they had done to impart knowledge with comfort for the years past in teaching MTB-MLE to the IP learners.

As presented in table 3, the coping strategies employed by Mother Tongue-Based teachers in IP schools produced five essential themes. These themes are self-retooling activities, Diversified teaching methods, Contextualized instructional delivery, Individualized instructions, and Acquaintance with the community. These themes generally refer to the essential activities of the teachers assigned in the IP schools.

As supported by the core ideas, respondents were very consistent with their answers and shared experiences. Thus, this 
further indicated that most of the respondents shared the same coping strategies in dealing with their difficulties in teaching MTB-MLE with their IP learners. It was also noted in the results that the importance of the community involvement and the activities provided aided the teachers in coping with the difficulties of providing the IP learners with instructions.

\section{Insights and Lessons Shared to the Community}

The insights and lessons shared by the respondents were really reflected in this study based on the struggles and difficulties they had encountered. The strengths and coping mechanisms that the MTB-MLE teachers presented in this study served as the ingredients for the participants to provide fruitful and meaningful insights and lessons. During the actual conduct of the FGD and IDI, most of the participants were very emotional in sharing the things that they had learned and the wisdom that they had gotten from teaching MTB-MLE to the IP learners.

In table 4, themes were formed from the respondents' answers to the questions about their insights and lessons shared with the community. Based on the respondents' answers, themes were supported by the core ideas, as seen in the table below. The results in this section were also supported by the raw statements of the participants.

Reading these verbatim statements by some means gave realizations that there was always something to learn from these teachers who were really trying hard just to deliver quality education to our IP learners. These teachers also ensured that equality among tribes and preserving their native language, culture, and traditions were always their top priorities.

\section{Struggles and Difficulties of Mother Tongue-Based Teachers in IP Schools}

From the transcribed lived experiences during the indepth interviews and focus group discussions of the Mother Tongue-Based teachers and their struggles and difficulties in IP schools, the researcher coded the core ideas and had revealed five essential themes. They are Highly-Tasking Instructional Responsibilities, Challenging Use of Native Dialects, Difficulty with Unfamiliar Terminologies, Negative Effects to English Literacy, and Aiming for Positive Learning Outcomes.

\section{Coping Strategies Employed by Mother Tongue-Based Teachers in IP Schools}

Every problem had its own set of solutions. In this case, Mother Tongue-Based teachers' struggles, and difficulties led to the unique and practical application of their identified coping strategies based on their lived experiences teaching IP learners in IP schools. The themes were generated based on the participants' responses: Self-retooling Activities, Diversified Teaching Methods, Contextualized Instructional Delivery, Individualized Instruction, and Acquaintance with the Community.
The lived experiences of the Mother Tongue-Based teachers in IP schools provided concrete data gathered from this exertion and proved that mother tongue teachers in IP schools can develop learners' linguistic, verbal, and interpersonal skills through inclusive education. According to Domingo (2), Lifelong communication skills, decision-making, and problemsolving can be attained through interactive and integrative teaching modes.

\section{Insights Shared by Mother Tongue-Based Teachers to the Community}

After all the struggles and difficulties and the coping strategies employed by the Mother Tongue-Based teachers in IP schools were exposed in this study, the participants needed to also impart their insights and lessons learned from teaching the IP learners. As presented in Table 1, most of the participants of this study had served IP schools for 3 years and more, which was enough for us to learn from them. The following themes were highlighted from this section: The Need for Social Support; Provision of In-Service Trainings; Deep Understanding of Learners' Needs; Enhancement of Student-Teacher Relationship; and lastly, the Enrichment of Native Languages.

The need for social support was essential, as discussed by the participants, resulting in the realization that the constructivism theory was highly encouraged. Teacherparticipants had expressed the need for community assistance and mentoring from the local governing units, particularly the barangay where the IP school community belongs.

\section{Implications for Educational Practice}

The themes that emerged from the transcribed lived experiences of Mother Tongue-Based teachers in IP schools had clearly stipulated a new paradigm that improved their realizations on the vitality of their functions and gave more prominence to their responsibilities and commitment as a catalyst of change. For instance, the teacher's role may be somewhat highly-tasking sometimes. Too many responsibilities may be added to them. However, in the chosen path of our teachers, it was still innate to them to look for a positive way to address this problem.

The coping strategies employed by the Mother TongueBased teachers in IP schools indicated that self-retooling may sort to the solicitations of insights and lessons from former teachers, which will help the current teachers in IP schools survive the task deliver quality education for the IP learners. By listening to the seasoned teachers, one can also innovate and improve the practices to make them more functional to the IP learners.

The utilization of various localized teaching instruments or instructional materials will also aid the teachers in exploring the method of the indigenization process. Talking about the contextualized materials, the indigenization processes may be applied to almost all disciplines. They can teach a strong 


\section{EPRA International Journal of Multidisciplinary Research (IJMR) - Peer Reviewed Journal}

Volume: 8| Issue: 2| February 2022|| Journal DOI: 10.36713/epra2013 || SJIF Impact Factor 2021: 8.047 || ISI Value: 1.188

foundation of values formation and cultural appreciation. In terms of language teaching, teachers in IP schools also implied contextualization of their instructional delivery using various activities which provided relative and authentic situations or real scenarios to localize the lessons with ease and aptness.

With the teachers' willingness to know more about the indigenous people, the acquaintance with the community through the organization of an IP Day was suggested to promote harmony, understanding, and social support to the IP community. Moreover, the teacher's awareness of the IP community will help improve instructional plans that are most excellent for the IP learners.

The enhancement of the teacher and learner relationship was highly encouraged. Lots of activities may be provided to achieve the goal of being open with our learners. The importance of the feeling of belongingness was also highlighted. Teachers lightened the tasks in delivering the instructions for the IP learners if teachers were also willing to work hand-in-hand towards achieving the listed common goal.

\section{Implication for Future Research}

The limitation that was shrouded in this study was the number of participants which was included and was selected by the researcher wherein elementary school teachers in the identified IP schools in the Schools Division of Davao City, particularly in Marilog Districts A and B and within that, the researcher only interviewed 15 teachers. However, the assessment processes used by 15 teachers of Marilog District A and B that the researcher interviewed may not speak for the entire population of the Mother Tongue-Based teachers in IP schools in Davao City.

This study's results and findings will not guarantee generalization beyond these 15 participants. Aside from the lived experiences and their coping mechanisms on the challenges mentioned, the researcher was expecting that further studies may be conducted and made, which was highly associated with the IP education and mother-tongue instruction, in any part of the region or even in our country that would be

\section{REFERENCES}

1. Abdalla, Má, et al. "Quality in qualitative organizational research: types of triangulations as a methodological alternative." Administração: Ensino e Pesquisa, vol. 19, no. 1, 2018, pp. 66-98. ProQuest, https://www.proquest.com/scholarly-journals/qualityqualitative-organizational-researchtypes/docview/2009468460/se-2?accountid $=31259$, doi:http://dx.doi.org/10.13058/raep.2018.v19n1.578.

2. Alberto, Rosario, Gabinete, Sunny, \& Rañola, Vanessa. Issues and challenges in teaching mother tongue-based multilingual education in grades II and III: The Philippine experience. April 22, 2016. Available at SSRN 2768558.

3. Alieto, Ericson. Language Shift from English to Mother Tongue: Exploring Language Attitude and Willingness to investigated by more future researchers. The researcher suggested that potential researchers explore the orthography of the tribal community and their language preservations and the documentation and conservation of their practical native materials due to the lack of learning materials to be passed on to the next generations.

\section{CONCLUDING REMARKS}

As a grade-school teacher with a teaching background in IP school, the researcher chose to study the Mother TongueBased instruction in the context of teachers and the IP learners in different tribal communities. It is an educational issue that needs to be discussed addressed. The researcher found this study relevant to the character as a concerned teacher in one of the IP schools in Davao City, as a grader teacher, and as a student.

The researcher decided to have the qualitative research design to take the topic into a richer investigation. With the hint of notable theories, constructivists' notion in this study was highly observed. Teachers' constructive way of teaching the IP learners, with the help of their colleagues, lessened the tasks of dealing with difficulties. The Normalization Process theory, on the other hand, supported the embedding of instructional materials in language teaching. And finally, the Humanist theory suggests that to provide meaningful realization, experiences of the subject were highly organized, categorized, and analyzed into a new type of perspective.

The researcher witnessed the difficulties of the fellow teachers in IP schools in dealing with the Mother Tongue education and IP learners' native language in their daily instruction. The researcher's greatest desire was to uncover how the teachers teaching MTB in IP schools cope with the struggles and difficulties. The experiences and insights that the teachers in IP schools may illuminate the beginners or those teachers who were assigned to the IP schools with no background on what they are dealing with and help future teachers who would be facing the same condition.

Teach among Pre-Service Teachers. 2018. TESOL International Journal. Vol. 13(3), 134-146.

4. Amarles, Arceli M. "Multilingualism, Multilingual Education, and the English Language: Voices of PublicSchool Teachers". ${ }^{\text {st }}$ DTD Memorial Lecture. December 13, 2016. Linguistic Society of the Philippines. Vol. 47, 90-105.

5. Benson, Caroll. 'Multilingual education for all: Applying an integrated multilingual curriculum model to low-income contexts', in Coleman, H. April 2017. (ed.) Multilingualisms and development. London: British Council, pp. 101-113.

6. Benson, Caroll \& Young, Catherine. 'How can MTB-MLE be carried out in classrooms where three or more local languages are represented as mother tongues?', in Trudell, 2016. Good answers to tough questions in mother tongue- 
ISSN (Online): 2455-3662

EPRA International Journal of Multidisciplinary Research (IJMR) - Peer Reviewed Journal

Volume: 8| Issue: 2| February 2022|| Journal DOI: 10.36713/epra2013 || SJIF Impact Factor 2021: 8.047 || ISI Value: 1.188

based multilingual education. SIL International, pp. 1-7, 814.

7. Dacillos, Jerame Joi, Revealing the lived experiences of the public-school elementary teachers handling the mother tongue instruction: a phenomenology, April 2020.

8. De Los Reyes, Robin. Translanguaging in multilingual third grade ESL classrooms in Mindanao, Philippines. 2019. Translanguaging in multilingual third grade ESL classrooms in Mindanao, Philippines, International Journal of Multilingualism, 16(3), 302-316.

9. Jorolan-Quintero, Genevieve. "Oral Traditions: An Aid to Implementation of Mother Tongue-Based Multilingual Education in the Philippines' Basic Education Programme." International Review of Education, vol. 64, no. 6, 2018, pp. 759-777. ProQuest,

https://www.proquest.com/scholarlyjournals/oral-traditionsaid-implementationmothertongue/docview/210441021/se-

2 ? accountid=31259, doi:http://dx.doi.org/10.107/s1115918-9743-9.

10. Mangila, Benjamin. Institutionalizing a Mother TongueBased Approach in Teaching Multicultural Classrooms: A Closer Look at Elementary Teachers' Experiences. April 2019. Implementing the Mother Tongue-Based Multilingual Education Program in the Philippines: The Indigenous People (IP) Teachers' Experience.
11. Medilo, Constantino Jr.. The experience of mother tonguebased multilingual education teachers in Southern Leyte, Philippines. October 2016. In International Forum (Vol. 19, No. 2, pp. 64-79).

12. Mercado, Mark Gill. "Delivering Culturally Responsive Curriculum: A Case Study of IP School in the Philippines". 2020. Indigenous Peoples Education Research. DOI:10.5381/zendo.3969332

13. Metila, R. A., Pradilla, L. A., S., \& Williams, A. B. (2016). The challenge of implementing mother tongue education in linguistically diverse contexts: The case of the philippines. The Asia - Pacific Education Researcher, 25(5-6), 781-789. doi:http://dx.doi.org/10.1007/s40299-016-0310-5

14. Parba, Jayson. "Teachers' shifting language ideologies and teaching practices in Philippine mother tongue classrooms". Linguistics and Education, Volume 47, 2018, Pages 27-35, ISSN 0898-5898, https://doi.org/10.101/j.lingd.2018.077.015.

15. Quirante, Chareena. "The Future of Yogad: An Appreciative Inquiry on Mother Tongue-Based Multilingual Education Classroom Practices in the Philippines". 2018. Carleton University, Ottawa, Ontario.

16. Suhendi, Andang and Purwarno. Constructivist Learning Theory: The Contribution to Foreign Language Learning and Teaching, Knowledge E, 2018, knepublishing,com, https://knepublishing.com/index.ph 